\title{
Classroom Based Assessment Development for Improving Science Teacher's Competency in Secondary School at Koto Tangah District
}

\author{
Syamsurizal ${ }^{1}, \operatorname{Ardi}^{1}$, Arief Muttaqiin ${ }^{2}$ \\ ${ }^{1}$ Jurusan Biologi FMIPA UNP, ${ }^{2}$ Jurusan IPA FMIPA UNP \\ Correspondence: syam_unp@yahoo.co.id; Tel: +62-812-6709-150
}

Diterima 5 Maret 2018, Disetujui 5 Maret 2018, Dipublikasikan Maret 2018

\begin{abstract}
The aims of developing classroom based assessment for science teacher at secondary school in Koto Tangah district are enhancing the science teacher's competency and strengthening the principle of developing classroom based assessment. Participants are consisted of 35 junior high school science teacher in Koto Tangah district. Training and workshop method were used in this program to accomplish the goals. Before implementing the program, participants were given a prior knowledge about the basic rules of classroom based assessment. In addition, participants were given the instruction sheets to arrange the classroom based assessment and exercising to develop it with instructor's guidance.
\end{abstract}

Keywords -- assessments, science, secondary school

\section{Pendahuluan}

Pelaksanaan KTSP dan Kurikulum 2013 menghendaki adanya perubahan kegiatan pembelajaran di kelas, baik dalam cara guru mengajar maupun dalam melakukan penilaian proses dan hasil belajar siswa. Asesmen berbasis kelas merupakan implementasi dari pelaksanaan KTSP dan Kurikulum 2013.

Asesmen berbasis kelas dapat digolongkan sebagai penilaian autentik karena meliputi penilaian input (menilai kemampuan awal siswa terkait materi yang akan dibahas), penilaian proses (menilai proses pembelajaran) dan penilaian hasil (menilai kompetensi siswa setelah proses pembelajaran berlangsung), sehingga penilaian dapat dilakukan di awal, selama dan di akhir pembelajaran [1].

Assesmen berbasis kelas merupakan penilaian yang dapat digunakan guru untuk me-ngumpulkan feedback seawal, dan sesering mungkin mengenai seberapa baik siswa belajar, mengenai apa yang sedang siswa pikirkan dan mengenai apa yang sedang siswa kerjakan. Assesmen berbasis kelas merupakan suatu proses yang dilakukan guru melalui langkah-langkah perencanaan, pengumpulan sejumlah bukti yang menunjukkan pencapaian hasil belajar siswa, pelaporan, dan penggunaan informasi tentang hasil belajar siswa.

Peran assesmen berbasis kelas adalah memberikan masukan atau informasi secara komprehensif tentang hasil belajar siswa dilihat ketika kegiatan pembelajaran berlangsung hingga hasil akhir menggunakan berbagai cara penilaian sesuai dengan kompetensi yang diharapkan dicapai siswa. Dalam pelaksanaannya, penilaian tersebut bersifat internal, artinya hanya dilakukan oleh guru yang mengasuhnya, terus menerus dan merupakan bagian yang tidak terpisahkan dengan kegiatan belajar mengajar.

Pengumpulan informasi dan bukti-bukti pencapaian hasil belajar siswa dapat dilakukan secara formal (tes) maupun informal (non tes). Beberapa prinsip yang perlu diperhatikan dalam melaksanakan penilaian hasil belajar peserta didik adalah kesahihan, objektif, terpadu, terbuka, adil, akuntabel, sistematis, beracuan criteria, akuntabel, menyeluruh dan berkesinambungan [2].

Dalam pelaksanaan assesmen berbasis kelas, guru perlu memperhatikan prinsip- 
prinsip dasar yang harus digunakan sebagai berikut: berorientasi pada kompetensi, valid, adil, terbuka, berkesinambungan, menyeluruh, bermakna, dan mendidik. Ciri-ciri assesmen berbasis kelas [3] adalah sebagai berikut: mengacu ke kompetensi, komit pada partisipasi aktif siswa, mengarah pada penilaian berkelanjutan, bersifat kontekstual spesifik, memberikan umpan balik, dan mendasari praktek mengajar yang baik.

Dengan demikian dapat dipahami bahwa penilaian berbasis kelas merupakan suatu usaha untuk membangun proses pembelajaran yang lebih baik dengan melakukan umpan balik pada cara belajar siswa secara lebih sistematik, lebih fleksibel, dan lebih efektif. Penilaian ini memberi suatu cara untuk melakukan penilaian secara menyeluruh dan sistematik dalam proses belajar mengajar di kelas.

Berdasarkan wawancara penulis dengan beberapa orang guru IPA SMP dan MTs di Kecamatan Koto Tangah, ternyata mereka masih mengalami kesulitan dalam memahami dan mengembangkan assesmen berbasis kelas karena prinsip dan strategi mengaplikasikan penilaian berbasis kelas agak kompleks. Melihat hal demikian, penulis merasa tertarik untuk melakukan pengabdian kepada masyarakat tentang pembuatan assesmen berbasis kelas untuk guru IPA SMP dan MTs Kecamatan Koto Tangah.

Berdasarkan fakta yang sudah diuraikan dan mengingat pentingya assesmen pembelajaran berbasis kelas, maka dapat dirumuskan masalah bahwa mitra IbM secara umum belum paham dan belum terampil dalam pengembangan assesmen pembelajaran IPA berbasis kelas yang meliputi: 1) Perancangan asesmen satu semester; 2) Asesmen kinerja; 3) Asesmen projek; dan 4) Asesmen portofolio.

Tujuan kegiatan pelatihan pengembangan asesmen berbasis kelas diantaranya adalah untuk memberikan keterampilan pengem-bangan assesmen berbasis kelas; dan memberikan penyegaran tentang kaidah assesmen berbasis kelas.

Manfaat kegiatan pelatihan pengembangan asesmen berbasis kelas diantaranya adalah untuk meningkatkan keterampilan pengembangan assesmen berbasis kelas guru IPA SMP dan MTs; dan meningkatkan pemahaman guru IPA SMP dan MTs tentang kaidah assesmen berbasis kelas.

\section{Tinjauan Pustaka}

Asesmen merupakan suatu instruksi instrinsik yang efektif untuk meninjau hasil belajar peserta didik di kelas [4]. Dengan dilakukan asesmen, dapat dilakukan pengukuran hasil belajar untuk mengetahui sejauh mana peserta didik mampu mencapai kompetensi yang ditargetkan.

Lebih lanjut, asesmen berbasis kelas bertujuan untuk menunjukkan pencapaian hasil belajar mahasiswa karena dapat menjabarkan pencapaian hasil belajar beserta kompetensi yang telah dicapai [5]. Dengan demikian, asesmen berbasis kelas merupakan metode penilaian yang dianggap ideal untuk dilaksanakan di kelas dalam proses pembelajaran.

Salah satu target yang ingin diukur dalam pelaksanaan asesmen berbasis kelas ini adalah kemampuan berpikir tingkat tinggi. Hal ini dikarenakan kemampuan berpikir tingkat tinggi telah dikukuhkan dalam kurikulum 2006 yang meliputi cara berpikir dan bernalar dalam menarik kesimpulan; mengembangkan aktifitas kreatif yang melibatkan imajinasi, intuisi, dan penemuan; dan mengembangkan kemampuan memecahkan masalah [6].

Kemampuan berpikir tingkat tinggi itu sendiri sangat menuntut pemikir (dalam hal ini peserta didik) untuk berpikir mengenai situasi atau kondisi, keterampilan dan hasil belajar yang ideal [7]. Lebih jauh, Lewis 
dan Smith menyatakan bahwa berpikir tingkat tinggi terdiri dari beberapa jenis, diantaranya adalah berpikir kritis, pemecahan masalah, pengambilan keputusan dan berpikir kreatif [7].

Kemampuan berpikir tingkat tinggi merupakan kemampuan yang perlu dilatihkan dan dapat diukur. Pengukuran terhadap kemampuan berpikir tingkat tinggi didasarkan pada ranah taksonomi bloom. Dengan menggunakan taksonomi Bloom, guru memiliki kesempatan untuk menananamkan kemampuan berpikir tingkat tinggi yang terstruktur kepada peserta didik, misalnya dengan memberikan pertanyaan-pertanyaan terbuka saat pembelajaran berlangsung, khususnya saat diskusi [8].

\section{Materi dan Metode}

Salah satu cara yang dapat ditempuh untuk mengatasi kesulitan guru IPA/ Biologi SMP dan MTsN Kecamatan Koto Tangah membuat assesmen berbasis kelas adalah dengan cara melaksanakan lokakarya dan memberikan pelatihan kepada guru. Dengan diberikan keterampilan membuat assesmen berbasis kompetensi kepada guru, maka kesiapan dan wawasan guru dalam menyongsong berlakunya Kurikulum Nasional (Kurikulum 2013 Revisi) di SMP dan MTsN dapat dijalankan dengan sebaikbaiknya.

Berdasarkan kerangka pemecahan masalah yang telah disusun yaitu melaksanakan pelatihan pembuatan assesmen berbasis kelas terhadap guru IPA SMP dan MTsN Kecamatan Koto Tangah, kegiatan ini sudah dapat dilaksanakan dengan baik. Perekrutan peserta pelatihan bekerjasama dengan musyawarah guru mata pelajaran IPA kota Padang. MGMP IPA bersama pemrakarsa kegiatan pelatihan mengundang para guru IPA SMP dan MTsN di Kecamatan Koto Tangah.
Mereka yang bersedia mengikuti kegiatan pengabdian, diminta mengisi formulir pernyataan kesediaan mengikuti pelatihan.

Alur kegiatan pelatihan dilakukan sebagai berikut:

1. Rekrut peserta

Sesuai dengan rencana peserta pelatihan berjumlah 25 orang guru IPA SMP dan MTsN di Kecamatan Koto Tangah.

2. Penyampaian materi pelatihan

Materi pelatihan yang disampaikan adalah tentang pengembangan asesmen berbasis kelas untuk peningkatan kompetensi guru IPA yang dijabarkan sebagai berikut:
a. Pengembangan
asesmen pembelajaran IPA

b. Karakteristik Asesmen Kurikulum 2013

c. Asesmen Otentik: knowledge, affective dan skills and ability; dan Asesment otentik menurut Kurikulum Baru (2013)

d. Penilaian kelas berbasis HOTS (Higher Order Thinking Skills).

e. Penilaian kelas berbasis pengetahuan dan keterampilan: tes tulis, tes lisan, penugasan, tes praktik, penilaian proyek dan portofolio.

f. Penilaian sikap: observasi, penilaian diri (self-assessment).

Dalam diskusi dan latihan membuat alat evaluasi peserta pelatihan dikelompokkan menjadi kelompok yang lebih kecil supaya proses latihan pembuatan soal lebih serius dan intensif. Pada sesi latihan inilah terjadi diskusi yang alot antara pembimbing dengan peserta sebab pada sesi ini terjadi dialog yang kontekstual sesuai dengan minat guru yaitu penilaian berbasis kelas dalam pelajaran IPA.

Khalayak sasaran dalam kegiatan pelatihan adalah 25 orang guru IPA SMP 
dan MTsN yang tersebar di Kecamatan Koto Tangah.

Metode yang digunakan dalam program ini adalah berupa pelatihan keterampilan membuat assesmen berbasis kompetensi. Sebelum dilakukan pelatihan, semua peserta lebih dahulu diberi wawasan tentang kaidah-kaidah utama dalam penyususunan assemen antara lain:hakekat penilaian hasil belajar IPA berbasis kelas; pengembangan asesmen autentik: pengembangan asesmen kognitif; pengembangan asesmen psikomotor; pengembangan asesmen afektif; dan pengembangan asesmen berbasis HOTS.

Selanjutnya peserta diberikan lembaran petunjuk pembuatan tes hasil belajar dan tiap kelompok membuat tes hasil belajar dan dibantu tim pelaksana program.

Untuk mengetahui keberhasilan program, maka dilakukan evaluasi terhadap peserta pelatihan. Evaluasi dilakukan pada dua tahap yaitu ketika kegiatan sedang berlangsung dan pada akhir kegiatan. Ketika kegiatan berlangsung dilakukan evaluasi terhadap peserta yang sedang melakukan praktek membuat assesmen. Pada saat tersebut, setiap kesalahan yang dibuat peserta langsung dikoreksi sehingga proses pembuatan soal dapat berhasil. Pada akhir program setiap peserta dievaluasi dengan cara memberikan angket. Hasil angket akan dijadikan salah satu tolak ukur keberhasilan program. Tolak ukur keberhasilan adalah bila 80 persen peserta terampil membuat assesmen berbasis kelas.

\section{Hasil dan Diskusi}

Pelaksanaan kegiatan ini dilakukan melalui proses penyajian, pelatihan dan evaluasi kegiatan. Untuk mengetahui tingkat keberhasilan kegiatan ini maka setelah kegiatan dilaksanakan tanya jawab dan observasi terhadap peserta pelatihan. Sedangkan evaluasi hasil ditujukan untuk mengetahui keberhasilan kegiatan.
Beberapa hasil yang dicapai dari kegiatan pelatihan adalah bertambahnya pengetahuan peserta, khususnya yang berhubungan dengan keterampilan peserta dalam memahami dan mengaplikasikan hakekat penilaian hasil belajar IPA berbasis kelas, pengembangan asesmen autentik, pengembangan asesmen alternatif, pengembangan asesmen psikomotor, pengembangan asesmen afektif; dan pengembangan asesmen berbasis HOTS.

Terampilnya guru dalam menggunakan software yang bertujuan untuk mengetahui kualitas soal dengan cara melihat beberapa aspek, diantaranya validitas, reliabilitas, tingkat kesukaran, daya pembeda dan kualitas pengecoh.

Dalam diskusi dan latihan guru diajak melakukan analisis soal yang sudah diujikaan menggunakan perangkat lunak komputer. Sesuai dengan prosedur pengabdian yang direncanakan yaitu setiap peserta membawa laptop, maka setiap guru melakukan analisis terhadap soal yang sudah dibuat menggunakan lembaran jawaban siswa yang sudah disiapkan sebelumnya. Pada sesi latihan inilah terjadi diskusi yang alot antara pembimbing dengan peserta sebab pada sesi ini terjadi dialog yang kontekstual sesuai dengan minat guru. Pada saat ini seluruh tim pengabdian masyarakat terlibat langsung dalam membimbing guru.

Pada pelaksanaan kegiatan pengabdian kepada masyarakat ini, peserta dapat berkontribusi aktif selama kegiatan berlangsung. Tingginya motivasi peserta untuk melaksanakan pengembangan diri dalam aspek pengembangan asesmen autentik, asesmen alternatif, asesmen psikomotor dan pengembangan asesmen afektif serta pengembangan asesmen berbasis HOTS merupakan salah satu contohnya. 


\section{Kesimpulan}

Berdasarkan hasil pengamatan, dapat diambil kesimpulan bahwa kegiatan secara umum dapat dikatakan berhasil, baik dari segi proses penyajian maupun proses pelatihan selama penyelenggaraan. Seluruh kegiatan yang direncanakan terlaksana dengan baik berkat dukungan segala pihak. Dengan adanya kegiatan pengabdian ini, diharapkan peserta mendapatkan wawasan yang signifikan terkait dengan kegiatan asesmen atau penilaian berbasis kelas yang seyogyanya dilakukan sehari-hari. Demikian pula, besar harapan kami agar penilaian berbasis kelas ini tidak hanya sebagai wawasan, namun dapat diterapkan di sekolah-sekolah sasaran, yakni di SMP Kecamatan Koto Tangah.

\section{DAFTAR PUSTAKA}

[1] Alimuddin, "Penilaian dalam kurikulum 2013," Semin. Nas. Pendidik. Karakter, vol. 1, no. 1, pp. 23-33, 2014.

[2] Kemendikbud, "Panduan Penilaian Untuk Sekolah Menegah Atas," 2015.

[3] Kemendikbud, Panduan Penilaian Untuk Sekolah Menengah Atas. 2014.

[4] D. Wiliam, "What is assessment for learning?," Stud. Educ. Eval., vol. 37, no. 1, pp. 3-14, 2011.

[5] Wakhinuddin, "Pengembangan, Implementasi dan Pembuatan Perangkat Asesmen Berbasis Kelas Untuk Pembelajaran Mata Kuliah Sistem Pemindah Tenaga," Jur. Tek. Otomotif FT UNP Padang, vol. 17, no. September, pp. 608-614, 2011.

[6] E. Pujiati, E. Werdiningsih, and A. Prayitno, "Pengembangan Perangkat Pembelajaran Berbasis Masalah Dalam Pembiasaan Siswa
Berpikir Tingkat Tinggi," in Seminar Nasional Matematika dan Pendidikan Matematika (SENDIKA 2015), 2015, pp. 227-235.

[7] F. J. King, L. Goodson, and F. Rohani, "Higher Order Thinking Skills," Publ. Educ. Serv. Program, now known as Cent. Adv. Learn. Assessment. Obtido www.cala.fsu.edu, pp. 1-176, 1998.

[8] R. Collins, "Skills for the 21st Century: teaching higher-order thinking," Curriculum \& Leadership Journal, vol. 12, no. 14. p. http://www.curriculum.edu.au/leade r/teaching_highe, 2014. 